\title{
Reliability of Solid Rocket Propellant Grain Under Simultaneous Action of Multiple Types of Loads
}

\author{
Nikola Gligorijević1 \\ Saša živkovići ${ }^{1)}$ \\ Vesna Rodić ${ }^{1)}$ \\ Saša Antonović ${ }^{1)}$ \\ Aleksandar Milojković ${ }^{1)}$ \\ Bojan Pavković ${ }^{1)}$ \\ Zoran Novaković ${ }^{1)}$
}

\begin{abstract}
A case-bonded solid propellant rocket grain is subjected to many stress-inducing loads during the service life, due to temperature, extended polymerization, transportation, vibration, acceleration, aerodynamic heating etc. and finally due to the operating pressure in the rocket motor. Composite propellant is a viscoelastic material whose mechanical properties highly depend on temperature and strain rate and sometimes may vary in the range of use of rocket motors for several orders of magnitude. Relationships between stresses and strains are much more complex than for the elastic material. Therefore, the stress and strain analysis and estimation of safety factor under the action of each individual load is quite complex and sometimes impossible. An even greater problem occurs when multiple different types of loads act simultaneously. An extreme case occurs in the moment of rocket motor ignition. Then, the very fast load acts due to the pressure, at which the propellant tensile strength is high. At the same time, the very slow thermal load acts on the grain, and in these conditions the propellant tensile strength is low. The vector addition of the stresses and strains due to different loads is not possible. It is also not possible to define the equivalent or resultant values of tensile strength and allowable strain. The principle of adding the current damage is applied here, similar to the model of cumulative damage. In addition, due to the large variations in mechanical properties of the rocket propellant, it is necessary to apply the methods of mathematical statistics for assessing the propellant grain reliability and service life.
\end{abstract}

Key words: rocket motor, propellant grain, composite propellant, viscoelasticity, stress, tensile strength, damage, reliability.

\section{Introduction}

$I_{s}^{N}$ $\mathrm{N}$ the theory of elasticity, under the assumption of small strains [1], in environmental conditions within the normal temperature range of use, under the uniaxial extension, there is a linear ratio between stresses and strains. It is also considered that the value of ultimate tensile strength is approximately constant, as well as the corresponding value of allowable strain.

The safety factor of an elastic body is defined as the ratio between the constant value of the material ultimate strength $\left(\sigma_{m}\right)$ and maximum equivalent stress $\left(\sigma_{0}\right)$, which is a resultant of stresses caused by different loads.

Sometimes, the safety factor may be also defined as the ratio between allowable strain $\left(\varepsilon_{m}\right)$ and equivalent strain $\left(\varepsilon_{0}\right)$ defined as the vector sum of individual strains due to different loads. Then we have:

$$
v_{\sigma}(t)=\frac{\sigma_{m}}{\sigma_{e}} \text { or } v_{\varepsilon}(t)=\frac{\varepsilon_{m}}{\varepsilon_{e}}
$$

This definition is quite simple because it implies that various types of loads and the manners that act onto the elastic body, have no effect on the ultimate strength or allowable strain of elastic material $\left(\sigma_{m}, \varepsilon_{m}\right)$, that remain nearly constant in all conditions.
The maximum equivalent stress $\left(\sigma_{0}\right)$, or corresponding maximum equivalent strain $\left(\varepsilon_{0}\right)$ is defined as the largest resultant of different simultaneous stresses (or strains), induced under the various load actions on the body, also regardless the mode of the load action.

For a viscoelastic material, like composite solid rocket propellant, the situation is completely different, because its mechanical properties are highly dependent on the temperature, and vary by several orders of magnitude within a temperature range of rocket motor use. In addition, mechanical properties of the propellant also highly depend on strain rate [1-3]. Since different loads produce different strain rates, the propellant mechanical properties will vary with different loads. That means, for example, that if the very slow temperature load acts onto the propellant grain in the rocket motor, it produces low strain rate, and also very low propellant tensile strength, in comparison with the case when another fast load acts. When the rocket motor works, pressure during the ignition and combustion is high, and the operating loads are fast. They produce high strain rate and the propellant tensile strength is entirely different and very high.

These two values can also differ in several orders of magnitude. A good advantage for the structural analysis of viscoelastic bodies, like propellant grain, is that there is „, a fortunate, although essentially unexplained" [2] association between temperature and strain rate.

\footnotetext{
1) Military Technical Institute (VTI), Ratka Resanovića 1, 11132 Belgrade, SERBIA

Correspondence to: Nikola Gligorijević; e-mail: nikola.gligorijevic@gmail.com
} 
For these reasons it is not possible to estimate the safety factor for viscoelastic rocket propellant grain in the same manner as for an elastic body. At first, it is not possible to define the equivalent tensile strength, nor is it possible to define the equivalent stress generated in the viscoelastic body under the simultaneous action of different loads.

For viscoelastic body a different principle is applied. Each individual load has to be considered separately. Its influence produces some current damage, presented as a ratio between the induced stress (and strain) and corresponding ultimate strength (or strain). This ratio is a relative value less than unity, which occupies a part of the propellant grain capacity to withstand the fracture. Total current damage of the solid propellant grain, as a viscoelastic structure, can finally be obtained as the sum of all individual current damages under the mechanical influences of different loads that simultaneously act on the grain. Finally, the safety factor is determined as the reciprocal value of the total current damage.

The principle is basically simple, but the analysis may be complicated when environmental loads are changing over time. This paper presents an example of such an analysis.

\section{Rocket propellant ultimate strength variability}

Viscoelastic mechanical properties presentation

Mechanical properties of rocket propellant are temperatureand strain rate-dependent. Strain $(\varepsilon)$ is dimensionless, as a ratio of two lengths, elongation $(\Delta l)$ and basic length $\left(l_{0}\right)$. Strain rate $(R=d \varepsilon / d t)$ dimension is equal to the inverse time.

Since the effect of strain rate is basically the time effect, it can be said finally, that propellant mechanical properties depend on temperature and time.

Fortunately, a good circumstance is that there is a clear correlation between these two different influences, time and temperature [1-4]. Changing the strain rate (time influence) for a certain value $(\Delta R)$ at arbitrary constant temperature $(T=$ const $)$ may have the same effect as a certain temperature change $(\Delta T)$, when the strain rate is constant $(R=$ const $)$.

The most commonly used term for connecting the time and temperature influence is Williams-Landed-Ferry (WLF) equation $[5,6]$ :

$$
\log a_{T}=-\frac{C_{1} \cdot\left(T-T_{0}\right)}{C_{2}+T-T_{0}}
$$

$\log a_{\mathrm{T}}$ is usually called "time-temperature shift factor". The significance of this feature can be seen from the Fig.1. Tensile strength regression curves, on different temperatures, are shown for a HTPB composite rocket propellant [7-9]:

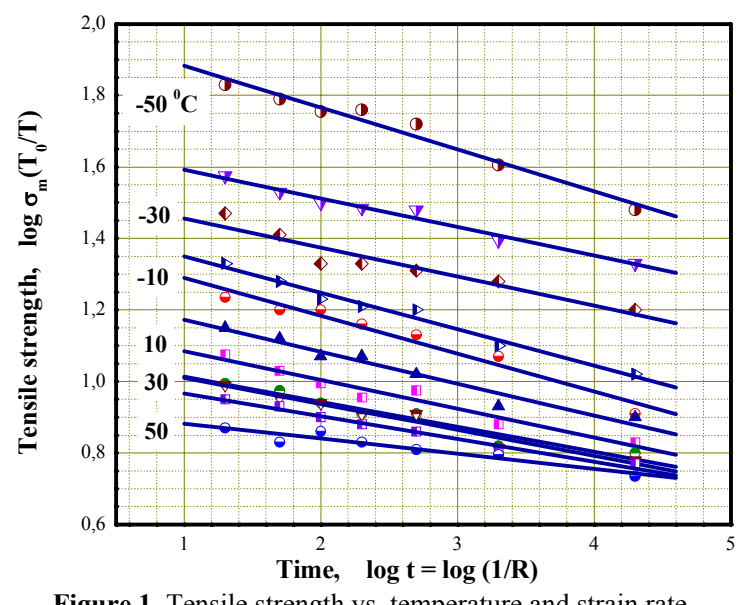

Figure 1. Tensile strength vs. temperature and strain rate
In the temperature range from $-60^{\circ} \mathrm{C}$ to $+50^{\circ} \mathrm{C}$, at $10^{\circ} \mathrm{C}$ increments, uniaxial tension tests were performed $[3,8,10]$ at several different tester cross-head speeds in the range between 0.2 and $1000 \mathrm{~mm} / \mathrm{min}$. For each constant temperature, a number of test points, equal to the number of different strain rates were obtained. These points form a curve for each temperature. Thus, regression curves for different temperatures were obtained.

These curves are approximately equidistant. Moving them horizontally, along the abscissa (time axis) to meet the reference line, will cause their overlap, creating a single common curve termed "master curve" [9]. It is necessary to choose an arbitrary temperature for a reference temperature. It is usually the standard ambient temperature $+20^{\circ} \mathrm{C}$.

Moving along the timeline, the curves that correspond to different arbitrary temperatures $(T)$ will overlap. It shows the correlation between temperature and time. The value of displacement is equal to the $\log a_{T}(\mathrm{~T})$.

It is customary (in all cited literature) to prepare the scale of the abscissa to represent both of the influences, temperature and time. Instead of reciprocal value of the strain rate $(t=1 / R)$, which has the dimension of real time, a single variable "reduced time" $(\xi)$ is introduced $\left(\xi=1 / R a_{T}=t / a_{T}\right)$, which is a combination of temperature and time (strain rate).

Finally, the tensile strength of the composite propellant as viscoelastic material can be displayed in the form of master curve which includes the strength dependence in all load conditions (Fig.2).

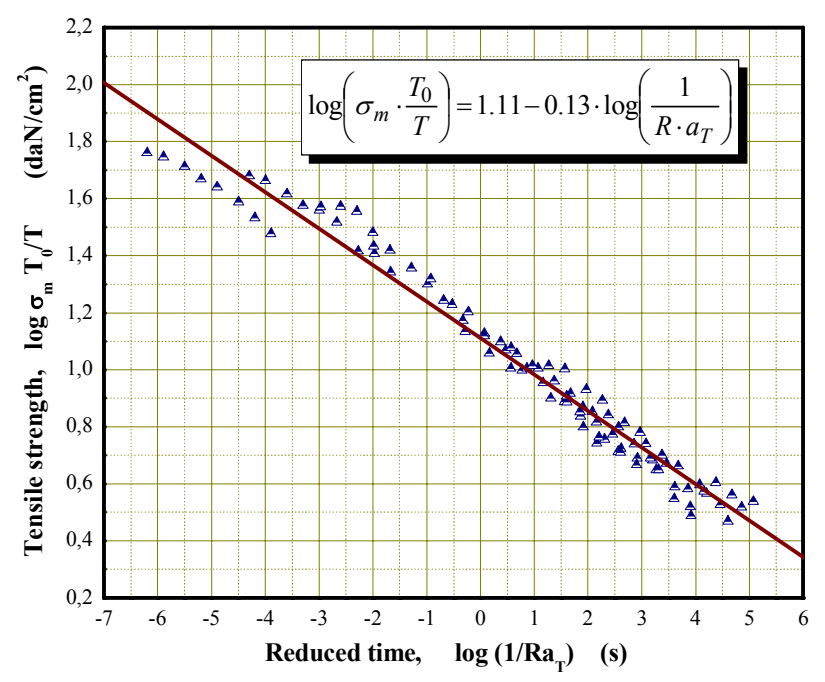

Figure 2. Tensile strength master curve

Since the elastic forces in polymers are proportional to absolute temperature $[1,3,4]$, tensile strength has to be normalized by a factor $\left(T_{0} / T\right)$.

\section{Tensile strength dependence on the type of load}

Propellant grain (2) (Fig.3), cast directly into the rocket motor chamber (1), suffers continuous stress due to the effect of the temperature difference between the casting and the ambient temperature. Strain rate after casting, made by the temperature difference, is quite small because the time period of propellant grain cooling down, after curing, up to the ambient temperature, is considerably long.

In another type of load, due to the pressure during the rocket motor ignition, the pressure is rapidly growing up and the strain rate is high.

Different strain rates affect the size of the propellant tensile strength. 


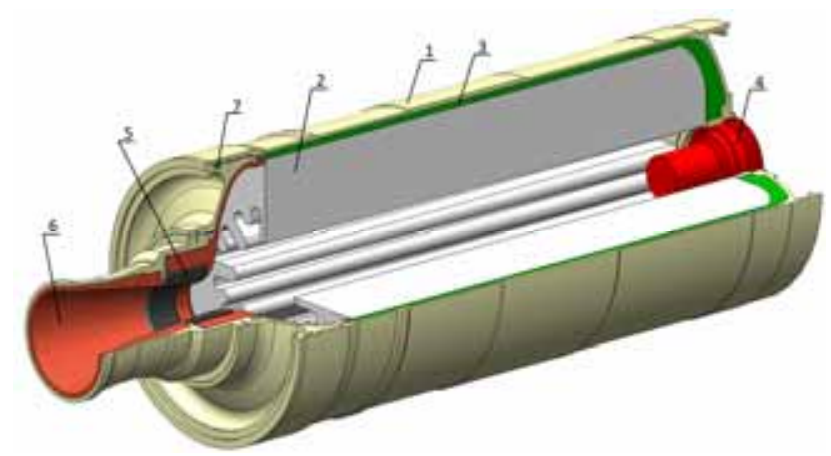

Figure 3. Rocket motor with cast composite propellant grain

Difference between the influences of these two values of strain rates can be seen in the case of tangential strain components in the hollow tube grain channel (Fig.4).

For the sake of comparison, let us consider the equations obtained in the elastic analysis, for tangential strain in the grain channel, due to the influence of temperature and the effects of increasing pressure during the rocket motor ignition.

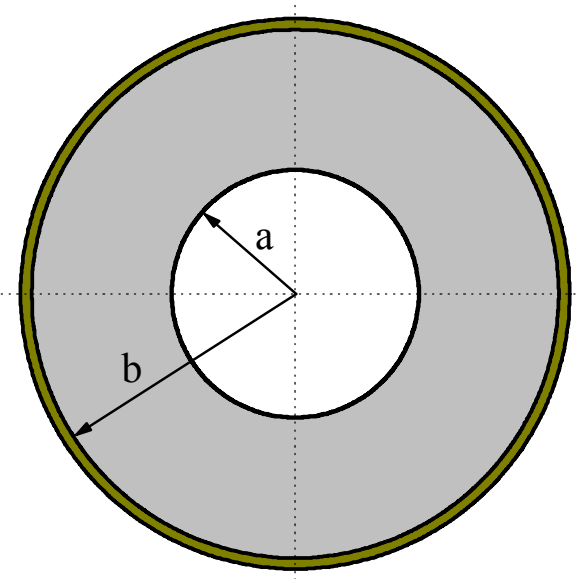

Figure 4. Hollow tube grain

In the case of pressure loading, the elastic equation for the tangential strain in the grain channel $[1,4,6 \div 8,10]$ has the following form (3):

$$
\varepsilon_{\theta}(p)=-\frac{(1+v) \cdot p}{E} \cdot\left\{1-2 v-\frac{2(1-v) \cdot K \cdot M^{2}}{M^{2}-1} \cdot\left[1-\frac{2(1-v)}{\Omega}\right]\right\}
$$

For the temperature loading, the following expression is taken from the same references:

$$
\varepsilon_{\theta}(T)=\alpha \cdot(1+v) \cdot \Delta T-2 K \cdot M^{2} \cdot \Phi \cdot(1-v) \cdot \Delta T
$$

Titles and explanations of all the features in these expressions are given in the Table 1. The features $\Omega$ and $\Phi$ can be obtained using the expressions:

$$
\begin{gathered}
\Omega=1+(1-2 v) \cdot M^{2}+\frac{E}{E_{c}} \cdot \frac{b}{h} \cdot\left(M^{2}-1\right) \cdot \frac{1-v_{c}^{2}}{1+v} \\
\Phi=\frac{\alpha(1-v)-\alpha_{c}\left(1-v_{c}\right)}{\Omega}
\end{gathered}
$$

For arbitrarily selected propellant grain (Fig.4) we can adopt the geometric properties and physical properties of the propellant [11], like in Table 1.

Since the load conditions were not known in advance, the propellant modulus value in the Table 1, which depends on

\begin{tabular}{|c|c|c|c|}
\hline$b$ & $\mathrm{~mm}$ & 50 & Outer radius of the grain \\
\hline$a$ & $\mathrm{~mm}$ & 25 & Inner radius of the grain \\
\hline$M$ & - & 2,0 & Outer/inner radius ratio \\
\hline$h$ & $\mathrm{~mm}$ & 2,0 & Case thickness \\
\hline$K$ & - & 2,0 & $\begin{array}{l}\text { Stress concentration in the star perforated } \\
\text { grain }\end{array}$ \\
\hline$T_{0}$ & $K$ & 293 & Reference temperature \\
\hline$v$ & - & $\approx 0,5$ & Propellant Poisson's ratio \\
\hline$v_{c}$ & - & $\approx 0,3$ & Case Poisson's ratio \\
\hline$E$ & $\frac{\mathrm{daN}}{\mathrm{cm}^{2}}$ & $\approx 600$ & Propellant modulus \\
\hline$E_{c}$ & $\frac{\mathrm{daN}}{\mathrm{cm}^{2}}$ & $2,1 \cdot 10^{6}$ & Case modulus of elasticity \\
\hline$\alpha$ & ${ }^{\circ} C^{-1}$ & $0,93 \cdot 10^{-4}$ & $\begin{array}{l}\text { Propellant coefficient of thermal } \\
\text { expansion }\end{array}$ \\
\hline$\alpha_{c}$ & ${ }^{\circ} C^{-1}$ & $0,11 \cdot 10^{-4}$ & Case coefficient of thermal expansion \\
\hline$C_{1}$ & - & 4.0 & \multirow{2}{*}{$\begin{array}{l}\text { Time-temperature shift factor } \\
\text { coefficients }\end{array}$} \\
\hline$C_{2}$ & - & 127,0 & \\
\hline
\end{tabular}
the strain rate, had to be approximately determined through several iterations.
Table 1. Propellant grain properties

Let us consider the tangential strain in the grain channel on the lowest extreme temperature of the rocket motor usage $\left(-40^{\circ} \mathrm{C}\right)$. During the rocket motor ignition, the operating pressure of approximately 200 bars is achieved in about 10 $\mathrm{ms}$. Furthermore, the propellant grain is cast at a temperature of $65^{\circ} \mathrm{C}$. After curing at this temperature, the grain was cooling down for about 12 hours to the ambient temperature of $+20^{\circ} \mathrm{C}$.

Replacing the values from the Table 1 into the expressions (5) and (6) we have $\Omega=1,013$ and $\Phi=0,383 \cdot 10^{-4}$. From the expressions (3) and (4) we get very similar absolute values and the same directions for the strains due to the effects of pressure and temperature:

$$
\begin{aligned}
& \varepsilon_{\theta}(p) \approx-0,0171 \\
& \varepsilon_{\theta}(T) \approx-0,0175
\end{aligned}
$$

Strain rate is defined as the ratio of strain and the time needed to achieve the strain:

$$
R=\frac{d \varepsilon}{d t} \approx \frac{\varepsilon}{t}
$$

Strain rates during rocket motor ignition and during the propellant grain cooling down after curing are shown in expressions (10) and (11):

$$
\begin{gathered}
R(p)=\frac{\varepsilon_{\theta}(p)}{t(p)}=-\frac{0,0171}{10 \cdot 10^{-3}}=1,71 \mathrm{~s}^{-1} \\
R(T)=\frac{\varepsilon_{\theta}(T)}{t(T)}=-\frac{0,0175}{12 h}=0,4 \cdot 10^{-6} \mathrm{~s}^{-1} \\
\log R(p)=\log (1,71)=0,233 \\
\log R(T)=\log \left(0,4 \cdot 10^{-6}\right)=-6,398
\end{gathered}
$$

Time-temperature shift factor for the rocket motor lowest working temperature $\left(-40^{\circ} \mathrm{C}\right)$ :

$$
\log a_{T}=-\frac{4\left(T-T_{0}\right)}{127+T-T_{0}}=\frac{4 \cdot(233-293)}{127+233-293}=3,582
$$


Reduced time on the abscissa of the tensile strength master curve (Fig.2):

$$
\log \xi=\log \left(\frac{1}{R \cdot a_{T}}\right)
$$

$$
\begin{gathered}
\log \xi_{\theta}(p)=\log \left(\frac{1}{R(p) \cdot a_{T}}\right)=-0,233-3,582=-3,815 \\
\log \xi_{\theta}(T)=\log \left(\frac{1}{R(T) \cdot a_{T}}\right)=6,398-3,582=2,816
\end{gathered}
$$

There is a significant difference between the two reduced times, under the influence of temperature and pressure effects. Tensile strength can be calculated from the master curve equation in the Fig. 2:

$$
\begin{gathered}
\log \sigma_{m} \cdot \frac{T_{0}}{T}=1,11-0,13 \cdot \log \left(\frac{1}{R \cdot a_{T}}\right) \\
\log \sigma_{m}(p) \cdot \frac{293}{233}=1,11-0,13 \cdot(-3,815)=1,606 \\
\log \sigma_{m}(T) \cdot \frac{293}{233}=1,11-0,13 \cdot(2,816)=0,744 \\
\sigma_{m}(p)=32,10 \frac{\mathrm{daN}}{\mathrm{cm}^{2}} ; \quad \sigma_{m}(T)=4,41 \frac{\mathrm{daN}}{\mathrm{cm}^{2}}
\end{gathered}
$$

The expression (16) shows a big difference between the propellant tensile strengths in the cases when the pressure and temperature loads act at the same time. In some other circumstances, this difference may be even greater.

\section{Propellant grain reliability criteria}

\section{Effects of a number of different loads}

It can be concluded that real stresses and strains in a viscoelastic body depend on the ambient conditions as well as on the type of load that acts on the body.

The safety factor cannot be calculated in the same way as in the case of an elastic body. In the case of an elastic material, the tensile strength is treated as a constant value. Then, the safety factor is defined as the ratio of the tensile strength $\left(\sigma_{m}\right)$ to the maximum real equivalent stress $\left(\sigma_{0}\right)$, as a resultant of the simultaneous action of different loads.

For a viscoelastic body, if several different types of time dependent loads $L_{1}(t), L_{2}(t), L_{3}(t) \ldots$ act on the body at the same time, at different loading rates, they produce several correspondent different stresses, $\sigma_{1}(t), \sigma_{2}(t), \sigma_{3}(t) \ldots$ The strain rates are also different, as well as tensile strengths that correspond to different loads $\sigma_{m 1}(t), \sigma_{m 2}(t), \sigma_{m 3}(t) \ldots$

It is not possible to consider these loads together. For that reason, the effects of individual loads have to be analyzed separately, using the concept of convolution [6], which is valid for linear-viscoelastic materials. Each of the individual loads creates a certain current damage. Each of the individual current damages represents the ratio between real stress and its appropriate ultimate stress. So, the first current damage is equal to the ratio between the stress $\sigma_{1}(t)$ and the corresponding first tensile strength $\sigma_{m 1}(t)$. The same principle applies to the second load, and to all other loads. As long as the sum of the individual current damages is less than unit, we can believe that there will be no grain failure.

The effect of simultaneous loads can be represented as the sum of corresponding damage increments. The same principle is used in the Miners cumulative damage law $[6,12]$ :

$$
\begin{aligned}
& d(t)=d_{1}(t)+d_{2}(t)+d_{3}(t)+\ldots \\
& d(t)=\frac{\sigma_{1}(t)}{\sigma_{m 1}(t)}+\frac{\sigma_{2}(t)}{\sigma_{m 2}(t)}+\frac{\sigma_{3}(t)}{\sigma_{m 3}(t)}+\ldots
\end{aligned}
$$

Total current damage is equal to the sum of the individual damages. And finally, according to the rules in the theory of elasticity, the safety factor of the body is equal to the reciprocal of the total damage:

$$
v(t)=\frac{1}{d(t)}
$$

The example with two main, but extremely different loads in rocket motor, pressure and temperature, shows that unlike the procedure for the elastic body, in the procedure of the structural analysis of a viscoelastic rocket motor propellant grain, it is necessary to make all functional dependences of its viscoelastic mechanical properties on temperature and strain rate.

As for mechanical properties of rocket propellant, as a viscoelastic material, in addition to the features of tensile strength and allowable strain, natural aging of viscoelastic material must be considered [11, 13-16], as well as the impact of cumulative damage $[9,17,18]$.

\section{Variability of the propellant grain safety factor}

The term damage, in classical terminology, indicates that the body has suffered a permanent injury. However, when we talk about "current damage" in the rocket motor propellant grain, the situation is different. This is not a term that means irreversible damage. "Current damage" is a part of the total resistance of the grain that is currently occupied by load action. It depends on the current loads and the external forces acting on the grain. Since the environmental loads, acting on the propellant grain, vary over the time, the "current damage" is a time-variable.

Some loads may act for a while, and then they disappear and their influence stops. It is possible, for a part of that influence, to remain after the load action, until the stress in the viscoelastic body completely relaxes.

In reference [9] the following example was discussed: a rocket is mounted under the wings of the plane, but it returned to its base and the rocket was not launched. What happened with the rocket motor? It suffered stresses at first, due to acceleration of the aircraft, then due to aerodynamic heating, also due to vibrations of the wings, and finally, the most intensive load due to the temperature difference. Each of these loads causes their partial current damage. Total current damage is:

$$
d(t)=d_{1}(t)+d_{2}(t)+d_{3}(t)+d_{4}(t)
$$

The first three loads terminate and the stresses caused by them relax and return to zero. Then, the value of total current damage decreases:

$$
d(t) \approx d_{4}(t)
$$

This example explains the usage of the term „current damage", which depends on the intensity of current loads. If the value of current damage was theoretically greater than 1 , this would mean that the grain would probably fail. On the other hand, if it is less than 1, this means that there is no grain failure. When the first three loads disappear, the remaining current damage will be only the part, due to environmental temperature $d_{4}(\mathrm{t})$. Some accumulated damage might remain, but it is almost negligible, if the loads were acting shortly, and sufficiently small not to exceed the critical values of the safety factor. 
Current damage differs, in comparison with "cumulative damage", which represents all accumulated damages due to the effects of previous loads, especially cyclic loads of high frequency $[17,19]$.

Current damage is the time dependent feature, even when only one environmental load acts onto the propellant grain. This is particularly evident when the cyclic loads are acting. For example, from the time the propellant grain is cured, until it has burned away, the ambient temperature oscillates over every day, making a cyclic stresses and strains in the grain, according to approximately sinus law $[7,8]$. Over the year, there is another sinus oscillation during the four seasons.

This damage originates from the large difference of coefficients of thermal expansion between propellant and rocket motor case. There are no stresses in the propellant during casting into the rocket motor chamber at a higher temperature (for example $+65^{\circ} \mathrm{C}$ ). After curing and cooling down, the stresses arise due to the difference between ambient temperature and zero stress temperature.

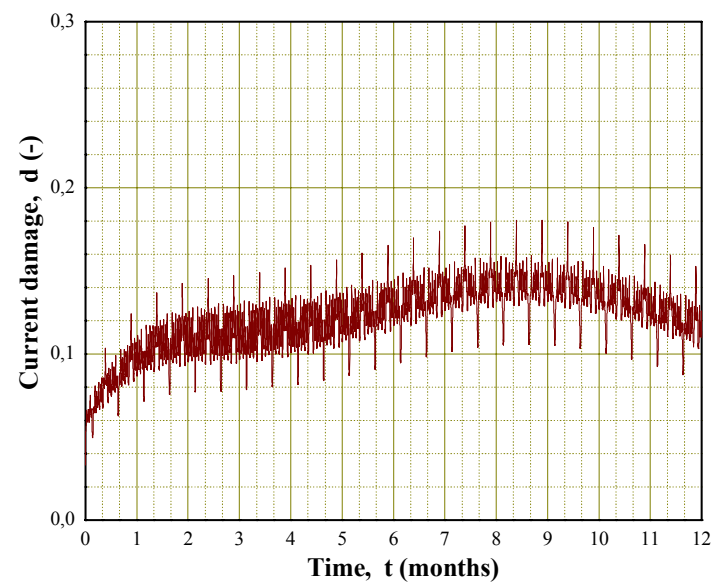

Figure 5. Annual current damage distribution in the rocket propellant grain due to environmental temperature

For a real rocket motor propellant grain, whose basic properties are defined in Table 1, the annual current damage distribution is calculated, due to the effects of environmental temperature (Fig.5). The current damage is caused due to daily and seasonal temperature changes.

Mathematical model for temperature distribution is made under the assumption that periodic jumps of the temperature appear in the regular time intervals. Therefore, in the Fig.5 there are the corresponding jumps of the current damage.

Any additional load causes the additional damage. According to this model for the linear-viscoelastic material, the total damage is equal to the sum of individual damages.

The current damage increases over time even if the loads are constant, because ultimate properties of the propellant degrade due to the aging and cumulative damage.

Therefore, the propellant grain safety factor must be considered as a time-dependent feature for two main reasons: due to the load variations and also due to the ultimate strength and allowable strain deterioration.

\section{Probabilistic approach to the failure criteria}

Fig. 5 shows large variations of the current damage only due to the temperature load. In this case, the current damage variations are not critical because they are much less than unity. However, when multiple loads operate simultaneously, and all of them vary extensively, the total value of the current damage varies even more. Then, it is almost impossible to accurately define its intensity.
In the case of temperature load, Heller and Zibdeh [15, 17, 20] recommended probabilistic methodology for evaluation of the propellant grain reliability. Based on this model, it is possible to define the similar model for the action of simultaneous loads.

For example, let us consider the case of tangential stress $\left(\sigma_{\theta}\right)$ in the propellant grain channel. Probability of a grain failure due to the first single load $\left(\sigma_{\theta 1}\right)$ may be the defined simply:

$$
P_{f 1}=P\left(\sigma_{m 1} \leq \sigma_{\theta 1}\right)
$$

Then, in the case of another, second load $\left(\sigma_{\theta 2}\right)$ we have:

$$
P_{f 2}=P\left(\sigma_{m 2} \leq \sigma_{\theta 2}\right), \text { etc. }
$$

Finally, the simplest assumption is that the events $1,2, \ldots, \mathrm{n}$ are independent, and probability of grain failure is the sum of individual probabilities:

$$
P_{f}=P_{f 1}+P_{f 2}+\ldots P_{f n}
$$

Although this model is not quite true, it may be acceptable in the absence of a better one. Further correction of this model is a matter of experience or research in the field of structural analysis.

This approach is based on statistical measures of all the mechanical properties of the propellant as a viscoelastic material, and also on determination the statistical parameters for all the real loads and stresses. It is suitable to assume normal statistical distributions.

\section{Propellant Grain Reliability}

After the termination of the short-term or concentrated loads influence, stresses in the propellant grain relatively quickly relax, without consequences for the grain. Unlike them, continuous cyclic loads of high frequencies can cause grain failure due to the cumulative damage [9, 17-19].

The impact of cyclic loads can be very small, especially when probability of failure is much lower than unit. However, there is always the possibility of cracking or some kind of failure due to loads repeated many times.

Let us suppose that all the single probabilities of the failure in expression (23) are due to the short-term loads, except one, which is caused by a cyclic load. All other probabilities will disappear with the end of the load, except the last one. At the end of each load cycle, such as daily fluctuations in temperature, the reliability is equal to the probability of the opposite event to the failure.

$$
R_{i}=1-\left(P_{f}\right)_{i}
$$

To calculate the grain reliability at the end of random cycle, it is necessary to get the probabilities at the end of each previous temperature cycle. After $(n)$ cycles, using the multiplication rule of dependent probabilities, the reliability is equal to an $n$ - fold production of single probabilities of surviving:

$$
\begin{gathered}
R_{n}=\left(1-P_{f_{1}}\right) \cdot\left(1-P_{f_{2}}\right) \quad\left(1-P_{f_{n}}\right) \\
R_{n}=\prod_{i=1}^{i=n}\left(1-P_{f_{i}}\right)
\end{gathered}
$$

For the propellant grain defined in Table 1, the final results of structural analysis, probability of failure and reliability are shown in Fig.6. On the probability curve (1) periodic irregularities that can be seen are the result of the mathematical model of temperature disturbances. 
The smooth reliability curve (2) is much clearer in comparison to the value of safety factor, which is equal to the reciprocal of the unclear variable value of current damage (Fig.5).

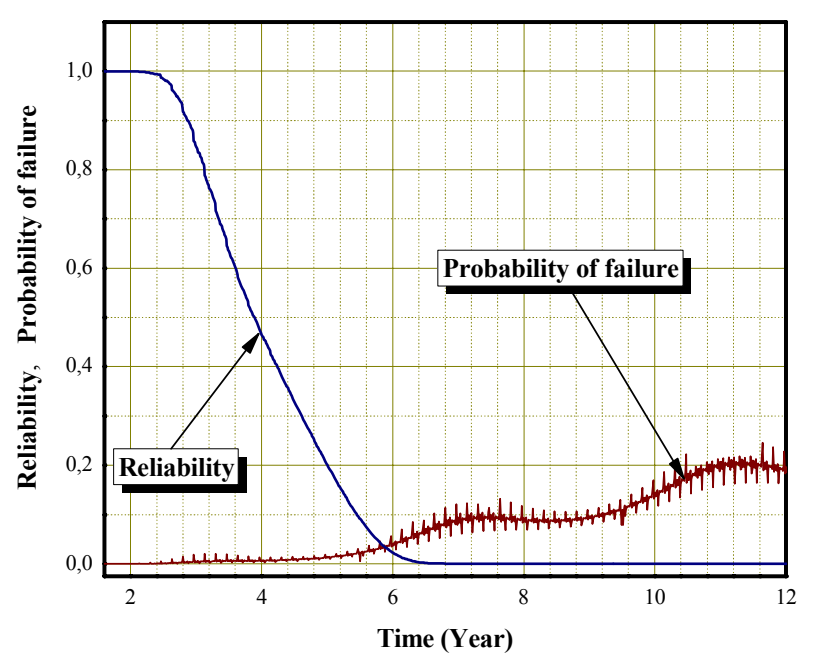

Figure 6. Reliability and probability of the grain failure

It is interesting that the grain reliability falls below the allowable value much earlier before the probability of failure reaches high values.

\section{Conclusion}

This paper discusses the specifics of structural analysis of solid rocket propellant grains as viscoelastic materials. The mechanical properties of the composite rocket propellant depend on many different factors, but most on the temperature and strain rate. Therefore, determination of the propellant grain safety factor and reliability is different in comparison with the elastic bodies. This procedure is quite complex and sometimes impossible. In engineering practice, due to the complexity, this problem is typically bypassed or ignored. Some empirical estimates are usually made, only on the basis of propellant test data made only in standard conditions. These estimates are usually inaccurate because they are not on a reliable basis. Testing the propellant mechanical properties only at the standard conditions does not have any practical application for the structural analysis, except perhaps as information, in order to compare the properties of different materials.

The structural analysis of viscoelastic materials is complex and involves a whole series of theoretical and experimental activities. This is especially evident when different loads simultaneously act onto a viscoelastic body. Their effects are also different because of the specific reactions of material, which is substantially different from the elastic material.

This paper is an example how the viscoelastic properties change due to the type and rate of loading. A modified classic model for the safety factor analysis is presented, under the multiple actions of two or more environmental loads, through the concept of linear sum of current damages and probabilistic approach to the evaluation of reliability.

\section{References}

[1] WILLIAMS,M.L., BLATZ,P.J., SCHAPERY,R.A.: Fundamental Studies Relating to Systems Analysis of Solid Propellants, Final report GALCIT 101, Guggenheim Aero. Lab., Pasadena, Calif., 1961.

[2] WILliamS,M.L.: Structural Analysis of Viscoelastic Materials, AIAA Jour., California Ins. of Tecnology, Pasadena, California, May 1964, pp.785-798.

[3] LANDEL,R.F., SMITH,T.L.: Viscoelastic Properties of Rubberlike Composite Propellants and Filled Elastomers, ARS J, 1960, Vol.31, No.5, pp.599-608.

[4] FITZGERALD,J.E., HUFFERD,W.L.: Handbook for the Engineering Structural Analysis of solid Propellants, CPIA publication 214, 1971.

[5] WILLIAMS,M.L., LANDEL,R.F., FERRY,J.D.: The Temperature Dependence of Relaxation Mechanisms in Amorphous Polymers and Other Glass-forming Liquids, Journal of American Chem. Soc., 1955, 77 (14),pp 3701-3707, DOI: 10.1021/ja 01619a008.

[6] Solid propellant grain structural integrity analysis, NASA Space Vehicle Design Crit. SP-8073, 1973.

[7] GLIGORIJEVIĆ,N.: Strukturna analiza pogonskih punjenja raketnih motora sa čvrstim gorivom, Naučnotehničke informacije, Vojnotehnički institut, Belgrade, 2013, Vol.XLIX, No.1, ISSN 18203418, ISBN 978-86-81123-59-1.

[8] GLIGORIJEVIĆ,N.: Istraživanje pouzdanosti $i$ veka upotrebe raketnih motora sa čvrstom pogonskom materijom (Solid propellant rocket motor reliability and service life research), Ph.D. Dissertation, Military Academy, Belgrade, Serbia, 2010.

[9] GLIGORIJEVIĆ,N., ŽIVKOVIĆ,S., RODIĆ,V., SUBOTIĆ,S., GLIGORIJEVIĆ,I.: Effect of Cumulative Damage on Rocket Motor Service Life, J Energ Mater, 2015, Vol.33, No.4, DOI: 10.1080 07370652. 2014.970245.

[10] МОСКВИТИН,В.В.: Сопротивление вјазко-упругих материалов, Наука, Москва (1972).

[11] GLIGORIJEVIĆ,N., RODIĆ,V., ŽIVKOVIĆ,S.B. PAVKOVIĆ,M., NIKOLIĆ,S., KOZOMARA,S., SUBOTIĆ,S.: Mechanical Characterization of Composite Solid Rocket Propellant based on hydroxy-terminated polybutadiene, Chemical Industry, 2015. DOI: 10.2298/HEMIND150217067G.

[12] MINER,M.A.: Cumulative Damage in Fatigue, J APPL MECH-T ASME, 1945, Vol.12, pp.159-164.

[13] GLIGORIJEVIĆ,N., RODIĆ,V., JEREMIĆ,R., ŽIVKOVIĆ,S., SUBOTIĆ,S.: Structural Analysis Procedure for a Case Bonded Solid Rocket Propellant Grain, Scientific Technical Review, ISSN 18200206, 2011, Vol.61, No.1 pp.1-9.

[14] CERRI,S., BOHN,A.M., MENKE,K., GALFETTI L.: Ageing Behavior of HTPB Based Rocket Propellant Formulations, CENT EUR J ENERG MAT, 2009, 6(2), pp.149-165.

[15] HELLER,R.A., SINGH,M.P.: Thermal Storage Life of SolidPropellant Motors, Journal of Spacecraft and Rockets, 1983, Vol.20, No.2, pp.144-149.

[16] GLIGORIJEVIĆ,N., ŽIVKOVIĆ,S., SUBOTIĆ,S., PAVKOVIĆ,B., NIKOLIĆ,M., KOZOMARA,S., RODIĆ,V.: Mechanical Properties of HTPB Propellants in the Initial Period of Service Life, Scientific Technical Review, ISSN 1820-0206, 2014, Vol.64, No.4, pp.1-13.

[17] HELLER,R.A., SINGH,M.P. ZIBDEH,H.: Environmental Effects on Cumulative Damage in Rocket Motors, J Spacecraft and Rockets, 1985, Vol.22, No.2, pp.149-155.

[18] LIU,C.T.: Cumulative Damage and Crack Growth in Solid Propellant, Media Pentagon Report No A486323 (1997).

[19] TORMEY,J.F., BRITTON,S.C.: Effect of Cyclic Loading on Solid Propellant Grain Structures, AIAA Journal, 1963, No.8, Vol.1, pp.1763-1770.

[20] ZIBDEH,H.S., HELLER,R.A.: Rocket Motor Service Life Calculations Based on the First Passage Method, J Spacecraft and Rockets, 1989, Vol.26, No.4, pp.279-284. 


\title{
Pouzdanost pogonskog punjenja raketnog motora pri istovremenom dejstvu različitih opterećenja
}

Vezano pogonsko punjenje u raketnom motoru tokom svog radnog veka trpi različita opterećenja, usled temperature, produžene polimerizacije, transporta, vibracija, ubrzanja, aerodinamičkog zagrevanja i konačno usled radnog pritiska u motoru. Kompozitno raketno gorivo je viskoznoelastični materijal čije mehaničke osobine značajno zavise od temperature i brzine deformacije i u rasponu parametara upotrebe raketnog motora mogu da variraju i po nekoliko redova veličina. Odnosi napona i deformacija su mnogo složeniji nego za elastični materijal. Zbog toga je njihova analiza, kao i procena stepena sigurnosti pri dejstvu nekog opterećenja složena i ponekad nemoguća. Još veći problem se javlja kada nekoliko različitih vrsta opterećenja deluje istovremeno. Pri dejstvu veoma brzog opterećenja usled radnog pritiska zatezna čvrstoća goriva je visoka. Istovremeno, kada vrlo sporo temperatursko opterećenje deluje na pogonsko punjenje, zatezna čvrstoća goriva je mala. Vektorsko sabiranje napona i deformacija u tom slučaju nije moguće. Takođe nije moguće ni definisanje rezultujuće vrednosti zatezne čvrstoće ili dozvoljene deformacije. U radu je primenjen princip sabiranja trenutnih oštećenja, slično modelu akumulacije oštećenja. Pored toga, zbog velikih varijacija mehaničkih osobina goriva, razmatrana je primena metoda matematičke statistike za određivanje pouzdanosti i veka upotrebe pogonskog punjenja.

Ključne reči: raketni motor, pogonsko punjenje, kompozitno raketno gorivo, viskoznoelastičnost, naponsko stanje, zatezna čvrstoća, oštećenje, pouzdanost.

\section{Надёжность твёрдого ракетного порохового заряда при одновременном действии различных типов нагрузок}

\begin{abstract}
Твёрдое ракетное зерно с корпусом ракеты подвергается воздействию многих нагружающих напряжений в течение срока службы из-за температуры, расширенной полимеризации, транспортировки, вибраций, ускорений, аэродинамического нагрева и наконец, из-за рабочего давления в ракетном двигателе. Композитное ракетное топливо представляет собой вязкоупругий материал, механические свойства которого в большой степени зависят от температуры и скорости деформации и иногда могут варьироваться в диапазоне использования ракетных двигателей на несколько порядков. Отношения между напряжениями и деформациями гораздо сложнее, чем для эластичного материала. Поэтому анализ напряжений и деформаций и оценка степени коэффициента безопасности под действием каждой отдельной нагрузки достаточно сложны, а иногда и невозможны. Ещё бо́льшая проблема возникает, когда одновременно действуют несколько разных типов нагрузок. Крайний случай предела прочности на разрыв происходит в момент зажигания ракетного двигателя. В то же время очень медленная тепловая нагрузка воздействует на пороховой заряд, и в этих условиях прочность на разрыв топлива низка. Векторное сложение напряжений и деформаций, вызванных различными нагрузками, невозможно. Также невозможно определить эквивалентные или результирующие значения предела прочности на разрыв или допустимые деформации. Здесь применяется принцип добавления текущих убытков (повреждений), аналогичный модели совокупного ущерба. Кроме того, из-за больших вариаций механических свойств ракетного топлива, необходимо применять методы математической статистики для оценки надёжности и срока службы порохового заряда.
\end{abstract} состояние, предел прочности на разрыв, повреждение, надёжность.

\section{Fiabilité de la charge propulsive du moteur à fusée sous l'action des endommagement variés}

\begin{abstract}
La charge propulsive liée dans le moteur à fusée subit différentes charges durant sa vie de travail à cause de température, polymérisation prolongée, transport, vibrations d'accélérations, chauffage aérodynamique et finalement de la pression de travail de moteur. Le propergol composite est un matériau viscoélastique dont les propriétés mécaniques dépendent beaucoup de la température et de la vitesse de déformation et peuvent varier plusieurs rangs d'ampleur dans la portée des paramètres d'emploi de moteur à fusée. Les relations entre la tension et les déformations sont beaucoup plus complexes que chez le matériau élastique. Pour cela leur analyse ainsi que l'estimation du degré de sécurité sous l'action d'une charge est complexe et parfois impossible. Le plus grand problème apparaît lorsque plusieurs types de charges agissent simultanément. Sous l'action d'une pression très rapide provoquée par la pression de travail la résistance à la tension est très haute. En même temps lorsque très lente charge thermique agit sur la charge propulsive la résistance à la tension de charge devient très petite. $L$ 'addition vectorielle de la tension des déformation n'est pas possible dans ce cas. Il n'est pas possible non plus définir les valeurs résultantes de la résistance à la tension ou des déformations permises. Dans ce travail on a appliqué le principe de l'addition des endommagements courants pareil au modèle d'accumulation d'endommagements. En outre à cause de grandes variations des propriétés mécaniques du propergol on a considéré l'emploi de la méthode de statistique mathématique pour définir la fiabilité et la durée de vie de la charge propulsive.
\end{abstract}

